\title{
Rasgos polémicos
}

\section{RÉPLICA A VICENTE HUIDOBRO}

En nuestro número de Septiembre de 1925 reprodujimos algunos párralos de los capítulos que Guillermo de Torre dedica al esfudio de la poesia de Vicente Huidobro en'su libro Liferaturas europeas de vanguardia. Publicamos posteriormente la réplica que el poeta chileno dió a las apreciaciones del critico español.

G. de T., que pudo ver en Atenea la reproducción del arfículo de V. H., estima que esta respuesta sno tiene los caracteres de una réplica definitivas. sino, por lo contrario, es el origen de la contrarréplica publicada por la revista. Allar,, que de Torre nos envia y que insertamos a confinuación.

REACIONISMO y megalomania: He ahi dos términos antes disimiles que, sin embargo. han adquirido últimamente una rara unidad y una absoluta identificación, con motivo de un exabrupto polémico dirigido inopinada y desviadamente contra mi. Autor responsable: el poeta chileno Vicente Huidobro. Arma delictiva: un pintoresco folleto panfletario rotulado. Al fin se descubre mi maestro. Objetivo: Tratar en él de defenderse de las indirectas acusaciones de plagio-o más propiamente, señalamientos de influencias de Herrera Reissig-hechas en un articulo titulado Los verdaderos antecedentes líricos del creacionismo en Vicente Huidobros, que publiqué en esta misma revisła (ALFAR, núm. 33. Septiembre 1923). No obstante el rótulo de ese ensayo-que figura como 
complemento al capitulo especial dedicado al creacionismo en mi libro .Literaturas Europeas de Vanguardia,-la parte concreta en que aludia a V. H. no llegaría a una columna. Dues bien: como réplica sproporcionadas a tan estricta alusión, V. H., generoso y desbordado, me dedica diez y seis páginas de un suplemento castellano a su revista .Creación, (Paris, Febrero 1924). integrada por ocho páginas... El detalle es pintoresco, aunque halagador. Ahora bien: si yo siguiera esta escala de progresiones ascendentes necesitaria todo un número de esta revista o quizá un volumen de 400 páginas. Mas tranquilícese el lecior: seré mucho más comedido espacial y conceptualmente en esta contrarréplica - última y definitiva, - pese a probables, futuras y estériles contestaciones de mi contrincante.

* Lo primero que cruza por la mente del lector-aun por miope - benévolo que éste sea-de dicho folleto es una picante inlerrogación: ¿Acaso será también creacionista o más bien ecreado. , aunque extragramatical e inexistente, la prosa, el lenguaje polémico de V. H. como pretende serlo su poesia? Pues son tantas y de tal calibre las enormes incorrecciones idiomáticas acumuladas-faltas elementales y abundantísimas de sintaxis y ortografia-que hay ocasiones en que el lector pierde el sentido de párrafos tan lastimosos, sin concordancia ni puntuación. Y llega a sentir. el lector. con un ansia torturante, el deseo de inquirir la clase de idioma especial o jerga inusitada en que se halla redactado este zurdo panfleto. Mas luego echa de ver que si el lenguaje de V. H., por momentos, se parece algo al castellano y otros al francés. no llega, en puridad, a poder enclavarse en ninguno de ambos idiomas. Aunque el autor, de origen chileno, se cree bilingüe y tiene publicados libros, como es sabido, en español y francés, no llega a poseer ninguno de ellos. Advertiremos que contra lo que pudiera creerse no hay ninguna hipérbole ni añagaza polémica en esta afirmación. Y aunque para evidenciarlo los ejemplos pudieran ser numerosisimos, he aquí solamente algunos escogidos al azar.

En un párrafo de dicho folleto, V. H. escribe: \&Y como se me allargaron las orejas de oirlos (pág. 3). En otro habla de 
un centrenable cariño, pág. 9). Más adelante comienza asi un párrafo: -Mi espiritu irrespectuoso se recuerda. (pág. 10). Todo esto sin contar numerosos galicismos no corrientes, sino pertenecientes a la clase de inadmísibles, como depasar, es por eso que, influenciar, y faltas de ortografia que sonrojarian no yacomo los cuentos obscenos-a un guardia civil. sino a una cocinera o al más tosco gañán que fuese capaz de cometerlas: como malavarista, apuñaleando, silvaba, elc.

$\mathrm{Y}$ asi continuariamos subrayando las numerosas y pintoresćas pifias de su estilo -impecable, si no temiéramos que pudieran ser falseados nuestros propósitos y caracteristicas. Lamentaría ser confundido con cualquier purista fanáticamente ortodoxo. Y aun agregaré-aclaración innecesaria para los conocedores de mi fisonomia literaria-que no creo en la inmovilidad e impenetrabilidad de las lenguas, que tolero y practico ciertas extralimitaciones epersonales, de la ley gramatical... Mas de eso a las incorrecciones vergonzosas de $\mathrm{H}$., hay mucha distancia. Algún agudo gramático-tipo Casares-o satírico glosador de disparates léxicos-como el cuartelero y pacienzudo «Melitón González, - encontraría en el folleto huidobriano una abundante cantera para sus flagelantes divertimientos.

Finalmente-sin pasar de la superficie-las páginas incriminadas se ornan con una adecuada corona, un magnifico remate y grotesco florón. El Sr. V. H., queriendo aplastarme con el peso de los plagios, que, según veremos, me imputa, y para apoyar su pretencioso aserto de que yo me enurria de sus desechos. recuerda aquella célebre décima de Calderón-cuya procedencia él ignora probablemente, puesto que la cita como si fuese algo anónimo y popular. que ha llegado a él por tradición oral-que, como hasta los párvulos saben, comienza: - Cuentan de un sabio que un día...s Pues bien, V. H. copia los cuatro postreros versos, modificando asi el último:

-las migas que él arrojó,"

y evidenciándonos que para rebasar la medida de lo grotesco 
ignora el sentido de dicha décima, ya que permuta la sustancia nutritiva y se le atragantan unas -migas, en vez de las famosas -hierbas?.

Mas una vez puestos en pública evidencia este conjunto de pifias y desatinos, que por sí solos ridiculizan e invalidan de toda eficiencia crítica su folleto. entremos en su fondo (¿?) Advirlamos previamente que evitaremos toda reciprocidad, en cuanto a los gestos agresivos para mostrar nuestro desacuerdo con su tono polémico ridículo, inepto y de un mal guslo inexcusable. Quiere alardear de un fácil humorismo (¿a qué ese empeño de falsear voluntariamente mi nombre, escribiendo unas veces de Torres y otras Delorre?:-vengativamente yo pudiera ortografiar asi su nombre: Mr. Oui d'Aubrau, como Antonio Espina le llamó para ridiculizar su fallido afrancesamiento-) y sólo consigue arrastrarse penosamente por los arrabales de la bufonada más falsa y chabacaria.

La clave del método polémico utilizado por el emaravilloso hablistas, el eimpecable estilistas y el egenial creador, - asi habría de adjetivarle en reciprocidad burlesca-, se reduce al tosco e ingenuo procedimiento de defenderse acusando: esto es. no de enfilar razonamientos propios, sino argumentos ajenos vueltos del revés. imputando a los demás aquello de que habia sido acusado él. V. H., en lugar de aprestarse a demostrarnos que èl desconocía a Herrera Reissig. o que este poeta no influyó enormemente sobre su obra, como yo sosfenia, al extraer de sus poemas semidesconocidos un buen caudal de imágenes, deja vigente, con una réplica incompleta, tal acusación, y por el contrario me acusa a mi de haberle plagiado a él.

La semejanza que yo exponía en el siguiente paralelismo queda en pie. Escribe el magno Herrera Reissig, en su libro -Los parques abandonados, de 1908:

.Y se durmió la farde en tus ojerass.

Y como un eco lejano, más con la fidelidad de un calco mi- 
mético, repite Huidobro doce años después, en un poema .Tardes, de la revista .Grecias. Junio 1920:

«El dia muere en fus mejillass.

Asombrosa coincidencia-¿no, lector amigo?-para poder llamarse sólo eso. Y agregaba yo, tras esta confronlación en el ensayo aludido: He aqui, pues, el origen-uno de los orígenes-de las famosas imágenes creacionistas ecreadas. por V. H., cuya sexclusiva, y eprimaria, originalidad ahora más que nunca queda irrefutablemente negada. He ahi, pues, resumida toda la intención critica y el objetivo de mis argumentaciones: no negar caprichosamente. o en virtud de los dictados del gusto, la obra de V. H., sino reducirla a sus justas proporciones, desposeerla de una originalidad que no tiene, marcar sus filiaciones, su emplazamiento y su conexión con otras contemporáneas, oponiéndome al sistema egolátrico. obscurecedor y absorbente de su autor. quien da con ello pruebas de una falta absoluta de sentido critico comparativo y de una megalomania lamentable. Sobre todo, esto último. V. H. desearia probablemente que la historia de la Poesia comenzase en él. De ahi que. literariamente, sea tan obcecado y fanático. Sus susceptibilidades, sus pretensiones vanidosas no reconocen limites. Ha llegado a creer que sólo él tiene la autorización exclusiva para ayuntar palabras en un sentido determinado. Recuerdo que en cierta ocasión se llevaba las manos a la cabcza porque a su eimitado, y efectivo maestro Pierre Reverdy se le habia ocurrido, en un verso de su libro .Les jockeys camouflés,. hablar de la snuit polaire., después que Huidobro habia escrito los «Poemas árticos», cuyo sólo titulo implicaba, según él, un veto absoluto para los demás de la menor alusión metafórica hacia aquellas alturas...

Sólo este detalle verídico bastará al lector que le desconozca, para juzgarle. para conocer su psicología de vanidoso patológico y de megalómano incurable. Asi se comprende que queriendo combatirme no haya encontrado otro recurso más fá- 
cil que penetrar en mi libro de poemas .Hélices. (1918-1923). $\mathrm{Y}$ poema por poema, verso tras verso releerlos concienzudamente-cuánto honor, gracias!-animado del propósito de descubrir semejanzas, aunque sólo luesen formales, o más bien vocabulares, entre mis versos y los de sus libros, para arrojar sobre mí, como una losa, la imponente acusación de plagiario. Para ello. cualquier pretexto le basta. En la imposibilidad de hallar, por lo general. coincidencias fundamentales-ya que yo poseo motivos, predilecciones temáticas y fuentes de inspiración distintas a las del autor de .Ecuatorial., se conforma modestamente en querer marcar alguna semejanza en la manera de estruclurar el poema, de lograr las imágenes o de emplear ciertos adjetivos... que, por otra parte no se parecen en nada. según comprobaréis.

Asi V. H., según recuerda en un verso de .Ecuatorial,, escribe:

$$
\text { .Bajo el boscaje afónico...., }
$$

lo que a mi juicio, carece de sentido. ya que el bosque al contrario de ser afónico puede tener voz-líricamente hablando- y ya que en su espesura hallará resonancias en el eco. De ahí que explotando esa posibilidad metafórica yo haya escrito. como él recuerda indignado:

- Y hay un rojo crepifar final de estrellas incendiadas prendidas en el boscaje mullifónicos.

(Hélices, pág. 11).

¿Dónde, pues, está el plagio? ¿Dónde, siquiera, la analogía? Verdaderamente, la sagacidad de V. H. es temible y sus descubrimientos son estremecedores.

En vista de ello. sigamos analizando estos divertidos - y arbitrarios - paralelismos o señalamientos de plagios. V. H. trata de hacernos creer que el primer poema de mi libro, titulado .Dehiscencias, escrito en el estio de 1918 - y cuya primera versión apareció en la revista .Cervantes,, en Noviembre del mismo año - es una secuencia de su poema .Ecuatorialı, apa- 
recido por aquellos meses en Madrid. Yo invitaria a cualquier lector imparcial a que cotejase ambos poemas para comprobar la absurdidad de tal aserto. Se diria que V. H., aun pretendiendo lo contrario. paradógicamente me ha favorecido. ya que sería dificil encontrar dos trozos líricos más disímiles. En el mio prevalece un ansia de decontorsión vocabular, de innovación léxica - ambiciones que me poseian en aquel momento remoto y algo preconsciente, 1918, de mi evolución -: mientras que V. H., por el contrario. con un vocabulario limitadisimo. que raya en la indigencia. trata simplemente de ecubicar, percepciones sueltas, enfilando imágenes inconexas, más o menos logradas.

Pero da qué fin detenerse en discutir sus ejemplos, cuando incluso en su mania persecutoria llega a querer atisbar una posibilidad de plagio en versos absolutamente disimiles? Véase, si no. el ejemplo de una coincidencia fortuita... por discrepancia. Escribe él en shallalis:

- La tierra desnuda gira aún....

Y yo en sHélices, (pág. 11):

.La fierra estatifica su rotación?.

En cuanto a otras quiméricas similitudes que V. H. pretende señalar, con mengua para mi obra, por el hecho de hacer. intervenir en varios de mis poemas lodos los elementos cósmi$\cos$ y astrológicos, barajando desenfadadamente soles, lunas. estrellas y planetas, bastará replicarle que estas fuerzas, con las que él mismo ha jugado, no le pertenecen en manera alguna, ni puede sellarlas con su monopolio. Son, por cl contrario, y en cierto modo, elementos comunes a todos los poetas del cubismo literario, e cismos fraternos, a partir de Apollinaire: hasta pudiera decirse que pertenecen al acervo, al patrimonio general de la moderna lírica. Y, en rigor, seria dificil señalar un solo poeta de los años 1917-1922 que no haya hecho entrar en sus versos profusión de lunas, soles, estrellas, convertidas, por tal causa, en tópico pronto desprestigiado. 
En un capitulo de mi libro critico. y al explorar las caracteristicas de la imagen y la metáfora en la nueva lírica, hago ver: ccomo respondiendo al deseo de ofrecer una visión nueva, fresca y sorprendente del Cosmos, liberfado de las leyes fatales de causalidad, los poetas de las nuevas generaciones barajan y combinan caprichosa y divinamente lodos los elementos cósmicos y geográficos: De ahi la gran lluvia de estrellas, soles, lunas, trópicos y lineas meridianas que tejen insospechados contrastes en nuestros poetas dilectos. Y en apoyo de tal aserción entresaco diversos fragmentos:

Así lo mismo que Huidobro escribe en sEcuatorials:

- Lo luna nueva

con las jarcias rolas

ancló en Morsella esfa mañana..

equiparando este astro, simplemente, a un velero - lo que no marca ninguna extravitalización de aire creacionista - Jean Cocteau, en sus sPoésies, más audaz, y quizá anteriormente. ha escrito:

sa lune joue aux dominos.

y Reverdy que

sles ciprés tiennent la lune dans leurs doigts..

recordando, quizá, por otra parte, que ya en los tiempos románticos el buen Musset habia cantado - versos conocidisimos -

sc'elait dans la nuit brune

sur le clocher jauni

la lune

comme un point sur un $i$.

Además, Philippe Soupault, escribe en \&Westwegos:

-On pouvaif jouer avec le soleil qui se posaif comme un oiseau sur tous les monuments. 


\section{Rasgos polémicos}

E Ivan Goll, en „Paris, brûle»:

-Les icebergs glissent sur l'équateur

Les comefes battent de la queue.

Y más próximamente - excusadme - espigando en mi campo, recuerdo de mi poema ePleamars:

-Entre vendajes

aparece el sol fangencial

el rojo balandro solar. .

Y también dos kaikais (pág. 123 de sHélices»):

La luna:

es un semáforo astral

en el riel de la noche?.

-El sol:

es un monóculo que el día erguido

se coloca en su rostro.

Por analogía en la utilización de estos elementos evoco los siguientes versos de Eugenio Montes:

•lOh, los músculos del discóbolo

que arrojó al cielo el soll.

Y esle otro de Gerardo Diego, en -Imagens:

“...y la luna esta noche no reparte esquelas.

Comprobada, pues, hasta la saciedad esta unanimidad de los poetas últimos al emplear los elementos celestes y atmosféricos. fraguando con ellos algunas de sus más curiosas imágenes o admirables metáforas, ¿no resulta inaceptable y grotesco el ciego empeño monopolizador de V. H.? Pues éste pretende, por ejemplo, que una vez que él ha escrito en .Ecuatorials:

.Sobre el arco iris un pájaro..cantaba.

ya resultan imposibles, y más aún, plagios incontrovertibles, todas 
las alusiones al arco heplacrómico. Así él no concibe que yo haya tenido la ocurrencia de ver un

emagno arco iris resurrecto.

(.Dehiscenciar).

y menos aún cómo:

- Los arcos iris

salfan hipicamente el desierfor

( Resolo).

$\circ$

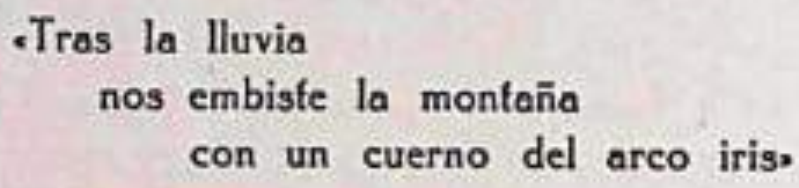

(.Estacións).

estrofas que, no obstante su paciente rebusca, él se olvida citar, pero yo me complazco — salvando toda inmodestia_en recordar para que el lector desapasionado compruebe hasta qué punto son inexactos, presuntuosos y desprovistos de todo fundamentoen la mayoría de los casos-los paralelismos establecidos por V. H. entre sus versos y los míos.

Sería pueril, dilatado y enojosísimo, por tanto, el ir refutando estrofa por estrofa, verso por verso, como él hace, las presuntas semejanzas y los supuestos plagios. Me limitaré por ello, a deshacer algunos otros de los errores que descuellan en el aludido folleto. Asi, respecto a ciertas frases de mi poema . Circuitos (pág. 19):

\section{- Entre mis piernas \\ permutan su cauce los ríos.}

que él cree inspiradas en ofras de Ecuatorial, diré únicamente que constituyen una parodia o parafrasis lírica de las palabras que Cansinos-Assens pone en mi boca, es decir, en las del «Poeta más joven», en el capítulo que a éste dedica en 
su novela El Movimiento V. P.s-historiografia bufa, como es sabido, sobre las gestas iniciales del ultraismo.

Respecto a mi poema .Torre Eiffel, (1920), unas lineas: Puesto que V. H. lo considera como un plagio o consecuencia innegable de otro suyo del mismo titulo. anterior en fecha (1918). yo por mi parte, y mostrándome por una vez condescendiente, lo aceptaré como tal. Mas a mi vez le haré ver el plagio o la secuencia innegable en que por su parte ha incurrido, recordándole que ya Apollinaire, hacia 1915 (Calligrammes), dedicó un pequeño poema a la eTours, bajo las iniciales de Robert Delaunay, autor del conocido cuadro cubista sobre el grandioso juguete del Champ de Mars. Que sugerido por la misma pintura, y en 1913. Blaise Cendrars dedicó otro poema a la Torre Eiffel, que puede leerse con el número 2 entre sus -19 Poèmes elastiques». Que, simultáneamente, o con poca diferencia de fechas, fiene olro Beauduin en $L$ homme cosmogoniques. Y que en varios poemas de Goll, Soupault. Berckelaers y Micic hay algunas alusiones o imágenes sobre el sugerente

-ärbol gigante

araña del cielo

cabellera del aire

pájaro elëctrico

hombre mecánico*

tal como yo me he permilido llamarla, desdoblando su visión en un poliedro de imágenes. Por otra parte. al cantar la Torre Eiffel, al eflirtearla, madrigalmente, yo no pretendia monopolizarla con un gesto único ni olvidar sus amantés anteriores, ya que en un párrafo me complazco en citar, entrecomiliadas, un ramillete de loanzas ajenas (ibidem. pág. 34). Véase, pues, cómo nuevamente, y ahora no sólo por mi culpa, sino por la confabulación de varios poetas, desde Apollinaire abajo, ha fracasado el monopolio absorbente de V. H. y su afán de encontrar en otros sus huellas, en vez de reconocer las ajenas en si mismo.

Para terminar, véanse, sin cornentarios, nuevos paralelismos... imposibles: 
«QQuién ha desenrollado el arco iris?.

(Huidobro).

-¿Quién ha fundido ese cable de estrellas?s

(•Hélices». pág. 40).

-Le soir on se promenera sur des routes paralléles.

(.Horizon carré). .

Cogidos de las manos

paralelamente

avanzamos con los cables y los rios. .

(.Hélices», pág. 45).

En fin, ¿a qué seguir fatigándonos y hastiando al lector? Hasta el más obtuso o el más parcialmente inclinado a V. H. quedará plenamente convencido de la arbitrariedad y la desfachatez de sus imputaciones y del fracaso de su folleto. Las analogias que en último extremo pudieran encontrarse entre nuestros libros son puramente externas y fortuitas, las obligadas entre coetáneos, entre espíritus oreados por el aire espiritual de la misma época. Mas en lo esencial, en lo que constituye la base de la personalidad, no podemos estar más lejanos. Ante todo por nuestra disparidad de temperamentos, clase de sensibilidad, predilecciones temáticas, etc. Mientras V. H. es en el fondo un espíritu irremisiblemente romántico. de abolengo simbolista, y sus poemas tienen un ritmo moroso y delicuescente, mi espiritu de filiación más moderna se halla solicitado por otros paisajes más dinámicos, y en consonancia mis poemas-los de la época de Aélices, - poseen un color muy diferente, más luminoso y jovial. Pero da qué más puntualizaciones, si lodos aquellos a quienes interese esta reivindicación de mi personalidad pueden hacerlo con la simple lectura del folleto y del libro incriminado?

Una aclaración postrera: respecto a la historia falseada de mi personalidad que apoyándose en textos de una fidelidad dudosa - como los de .Pombo Is - pretende esbozar, afirmaré que es ridicula e inadmisible. No niego la autenticidad de las cartas mías, de 1918, que V. H., malévolamente. transcribe en su fo- 
lleto: pero ha de saberse que éstas pertenecen al periodo que pudiéramos llamar de preconsciencia literaria, ya que entonces aun yo no tenía dieciocho años ni sentido exacto del valor de las palabras escritas, demasiado generosas o ingenuas. Por otra parte, el tono cordial y admirativo en que mis cartas aparecen redactadas, se explica fácilmente, porque entonces era muy otra la actitud en que $V$. H. parecia estar situado respecto a nosotros: en un plano cordial y leal, de espiritu adelantado sí, más en modo alguno magisterial e imperialista, como después se reveló. Mas todo ello, sus distintas fases, su actitud vis a vis del ultraismo, sus subrogaciones y maniobras salen ya fuera del radio polémico actual y está consignado fielmente en el capitulo de mi libro aludido. Cuya publicación no ha logrado impedir de ningún modo $\mathrm{V}$. H. pese a la intención subterránea de ese folleto y a las amenazas contenidas en un carla privada. de hace meses, que me vi obligado a devolverle, dándole una lección de cortesía, por no aceptar el estilo soez en que venía redactada. Con ella. según parece. V. H. pretendia introducir un nuevo sistema de smatonismo, incalificable en las relaciones literarias, superando el limite de los libelistas más procaces. Dero ¿qué ha de sorprendernos en una persona que, como él, apela al truco-o es su víctima-de las desapariciones misteriosas, después de Pierre Benoît, postulando la sréclame, y hablando al mismo tiempo de pureza y dignidad prolesional (il)?

\section{GUILLERMO DE TORRE.}

Madrid, Abril 1924.

(Revista Alfar de la Coruña (Esspaña) N.0 39. Abril de 1924). 